\title{
IMAGENS DO MATERIALISMO NOS CONTOS DE VOLTAIRE
}

\author{
Maria das Graças S. NASCIMENTO**
}

\begin{abstract}
RESUMO: Os contos filosóficos de Voltaire organizam-se a partir de dois pólos de reflexão: de um lado, a discussão sobre a noçào de uma providência divina benfeitora, e, em alguns casos, mais precisamente, sobre o otimismo leibniziano; de outro, a polemica em torno do materialismo ateu. Procuramos demonstrar de que modo, através de situações e personagens dos contos voltaireanos, a critica das teorias providencialistas contribui para delinear o universo próprio dos conceitos do materialisino clássico.
\end{abstract}

UNITERMOS: Voltaire; materialismo; materialismo ateu; contos filosóficos; otimismo filosófico; providência divina.

Jacques van den Heuvel, em seu excelente trabalho sobre os contos de Voltaire (8), havia observado a existência de dois períodos no processo de produção dos contos. $\mathrm{O}$ primeiro, anterior aos anos 67-68, ou seja, a época que se estende desde a publicação dos primeiros contos até o aparecimento do Ingênuo, incluindo portanto Micrômegas, Zadig e Cândido como os mais conhecidos, corresponderia a uma espécie de ficção onde o elo entre as experiências pessoais do autor e as suas próprias produções aparece em toda a sua transparência. Poder-se-ia dizer, em outras palavras, que nesta primeira fase, Voltaire, um introvertido quando se tratava de falar de si mesmo, teria conseguido expressar nos contos suas próprias angústias e'interrogações. Tal laço vivo entre o autor e sua obra teria dado origem a uma produção de grande qualidade. De outro lado, os contos posteriores a $O$ Ingênuo são considerados por Van den Heuvel como simples reedições ou sombras apagadas dos primeiros. A causa deste decréscimo de qualidade na ficção voltaireana estaria no fato de, após 1768, os contos terem se transformado em atividade panfletária, pois a intenção do autor de utilizar tais obras para servir a objetivos determinados é por demais evidente. Tal seria o caso principalmente do conto História de Jenni, concebido por Voltaire especificamente para servir de arma de combate contra o materialismo ateu.

Pensamos todavia que, se de um lado o julgamento de Van den Heuvel sobre a diferença de qualidade dos contos se justifica (não se pode negar a excelência do Cândido em relação a outros contos), de outro lado, a afirmação pura e simples de que o contista em idade avançada repete, e mal, o contista mais jovem precisa ser melhor esclarecida. Não há dúvida de que Voltaire se repete nos seus contos, no sentido de que certos temas, como o da providência e o da existência do mal, são retomados incansavelmente em quase todas as narrações. Quanto ao caráter panfletário deste tipo de obra de Vol-

\footnotetext{
* Departamento de Filosofia - Faculdade de Educaçào, Filosofia, Ciências Sociais e da Documentaçào - UNESP 17.500 - Marilia - SP.
} 
taire, pode-se dizer que ele se estende a todos os contos, mesmo àqueles que Van den Heuvel situa na primeira fase, na medida em que os propósitos aos quais a ficção serve de pretexto são sempre facilmente identificáveis. O Cândido não deixa de ser um panfleto contra o otimismo de Pope e Leibniz, $O$ Ingênuo, outro contra os jesuítas ou a mentalidade jesuítica, da mesma forma como a História de Jenni se dirige claramente contra o ateísmo.

Ao analisarmos pois os contos de Voltaire, entramos em contato direto com os temas de sua filosofia, que se apresentam nos contos com as mesmas características com as quais se manifestam nos textos ditos “teóricos". É por tal razão que um trabalho sobre as imagens de materialismo nos contos de Voltaire não pode de modo algum considerar apenas os contos que tratam especificamente dos temas da filosofia materialista, como, por exemplo, As orelhas do conde de Chesterfield ou a História de Jenni. A tomada em consideração dos outros contos é mesmo necessária, pois, mesmo quando Voltaire não discute diretamente o materialismo, a coincidência de seus temas de reflexão com os da filosofia materialista é inegável.

Tomados em seu conjunto, podemos observar imediatamente nos contos a permanência de três questões fundamentais. São elas: a afirmação da existência do mal no mundo contra a idéia de uma providência divina benfeitora, a defesa do sensualismo contra a teoria das idéias inatas e, por fim, a proposição segundo a qual as determinações que atuam sobre o destino dos homens são de natureza puramente material, mesmo banal, contra a idéia de um destino sobrenatural do ser humano. Ao discutir tais questões através dos episódios e personagens dos contos, Voltaire estimula o leitor a conciuir por respostas-limite e mesmo paradoxais. Assim, embora o anjo Jesrad, no Zadig, apareça para tentar conciliar o absurdo dos fatos com a idéia de providência divina, as desventuras sucessivas do personagem levam facilmente à conclusão de que tal providência é ineficaz. Do mesmo modo, no Cândido, ainda que o fato de poder cultivar o jardim sugira que, feito o balanço geral, o mundo não seria tão mau e a vida não seria tão difícil, o autor, entretanto, através de exageros e da caricatura, já havia sutilmente conduzido seus leitores à conclusão de que esse nosso mundo é realmente o pior dos mundos possíveis. Embora em quase todos os contos existam propostas conciliadoras para os paradoxos, elas são, na maioria das vezes, afastadas pelo autor, que propositadamente interrompe a discussão. Findo o conto, restam na mente do leitor respostas radicais. No entanto, História de Jenni, cujo alvo preciso é a filosofia materialista e ateísta, encerra uma proposta essencialmente conciliadora. Embora o texto apresente, no diálogo entre o sábio e o fanático, uma das investidas mais irônicas e violentas de Voltaire contra o cristianismo, no diálogo seguinte, entre o sábio e o ateu, a solução deísta é vitoriosa precisamente porque evita os excessos do fanatismo e do ateísmo.

Assim, vemos que ocorre nos contos voltaireanos o mesmo processo ocorrido em suas obras teóricas, ou seja, existem proposições nitidamente de caráter materialista subjacentes a ambas as espécies de textos. Voltaire, todavia, limita o alcance das conclusões materialistas no momento em que elas atingem a questão da existência de Deus. Aqui o autor recorre ao deísmo, solução intermediária, insatisfatória certamente, como o próprio Voltaire reconhece, mas isenta do risco do dogmatismo e mais apropriada a fundamentar a moral.

Retomentos pois a série dos contos. A principal pergunta à qual Voltaire procura responder através das aventuras de Zadig é colocada de uma maneira mais geral, se o homem pode ser feliz, e de uma maneira mais particular, se a sabedoria e a virtude podem trazer a felicidade. O conto Zadig ou o destino foi publicado inicialmente em 1747. Alguns episódios do conto só aparecem na segunda edição, de 1748, outros fo- 
ram acrescentados só em 1756, e ainda dois capítulos, “A dansa” e "Os olhos azuis" só foram publicados em edições póstumas. O personagem central, Zadig, é um homem puro, livre de preconceitos, jovem rico, desprovido de paixões, sem orgulho, generoso. Instruído nas ciências, Zadig possui todas as qualidades para ser feliz e viver tranqüilamente (23, p.5). Mas os acontecimentos que sobrevêm só concorrem para sua desgraça. Todo o Zadig é a história da intromissão de um "porém" no curso da felicidade.

Assim, às vésperas de seu casamento, Zadig é agredido por bandidos a mando de um rival e perde a visão de um olho; perde em seguida a própria noiva que não pôde aceitar sua semi-cegueira. Escolhe então para esposa uma mulher do povo, que ele crê mais virtuosa, mas que acaba também por trai-lo. Após tais desventuras conjugais, o herói resolve retirar-se no campo, onde, por sua vez, toda a sua inteligência e perspicácia lhe valem um mal-entendido que o condena ao exilio. Desfeito o mal-entendido, Zadig tenta encontrar na filosofia a consolação para seus males, mas sua sabedoria só provoca invejas, e um caluniador consegue, através de engenhoso artifício, colocá-lo na prisão. Felizmente a calúnia é desmascarada e nosso herói passa por um período de paz, e mesmo de certa glória. Mas a infelicidade logo está de volta e Zadig é obrigado a fugir. Aprisionado como escravo, suas virtudes atraem a benevolência de seu mestre, que decide libertá-lo. No entanto, novas desventuras o esperam, e assim sucessivamente. Até as cenas finais do conto, a vida de Zadig se apresenta como um fluxo e refluxo, onde as promessas de felicidade são constantemente desmentidas pelos fatos.

Em meio a este vaivém da tranquilidade, o herói faz as suas reflexões. Após o primeiro desgosto, Zadig julga que é difícil ser feliz, e que mesmo a sabedoria pode ser causa dos nossos males (23, p.12). Quando surgem períodos de paz, ele recomeça a crer na felicidade $(23$, p.16). Tantas desventuras, todavia, acabam por torná-lo desconfiado, mesmo durante as fases felizes da vida. Tal é o significado do sonho de Zadig descrito no episódio sobre as disputas e audiências. A imagem do leito de rosas do qual surge uma serpente venenosa retrata a própria vida do herói, acometido por constantes desgraças exatamente em ocasiões em que ele julgava ter finalmente encontrado a paz. Há momentos em que ele se desespera: “O que é pois a vida humana? Ó virtude! Para que me serviste? Tudo o que fiz de bom sempre foi para mim uma fonte de maldições... Se eu tivesse sido mau como tantos outros, eu teria sido feliz como eles o são' (23, p.26). "Enfim, escapou-lhe murmurar contra a providência, e ele foi tentado a acreditar que tudo era governado por um destino cruel que oprimia os bons" $(23$, p.57). A questão aqui se apresenta nos seguintes termos: ou a providência divina não existe, ou, se ela existe, trata-se de uma providência cruel. Neste momento, Voltaire faz intervir um personagem que tenta responder às interrogações de Zadig de maneira conciliatória. Tal personagem, um eremita que se transforma num dado momento no anjo Jesrad, procura justificar a existência do mal sobre a terra. Todo mal se justifica então na medida em que concorre para um bem geral. "Não existe, diz o anjo, nenhum mal do qual não nasça um bem”. E Jesrad continua: “O acaso não existe, tudo é prova, punição, recompensa ou prevenção’' $(23$, p.62-63). Segundo esta solução, o mal é pois um constituinte menor mas necessário no interior de um mundo que, considerado de maneira geral, obedece a um desígnio benfeitor.

A intervenção do anjo Jesrad, à primeira vista, podeia significar duas concessões de Voltaire. A primeira, feita ao sobrenatural, a segunda, ao otimismo de Pope e Leibniz. Em relação à primeira concessão, o fato de Voltaire introduzir um ser sobrenatural pode significar que a solução para o problema do mal só se encontra mesmo para além do mundo terreno, e, no caso tratar-se-ia mais de uma ironia de Voltaire, pois, segundo suas próprias palavras, "nós só possuímos a razão natural, tudo o que é sobrenatural está acima da nossa razão”' (11, p. 440). O que não deixa de ser um outro modo de di- 
zer que qualquer explicação do mundo que for incompreensível ao homem ser-lhe-á também inútil. Assim, a solução ao problema do mal por Jesrad, sendo sobrenatural, e portanto incompreensível, não pode satisfazer aos anseios da razão. Tal seria talvez o motivo pelo qual Voltaire teria interrompido a tentativa que faz Zadig de questionar as proposições do anjo. "Frágil mortal, diz Jesrad, cessa de disputar contra aquilo que é preciso adorar. Mas, diz Zadig,... E enquanto ele dizia "mas", o anjo voava em direção da décima esfera”' (23, p. 63). Zadig enião se submete.

A submissão de Zadig às exortações do anjo Jesrad seria uma concessão feita por Voltaire ao otimismo de Leibniz e Pope? Tal é a opinião de Van den Heuvel quando dá a entender que, nos anos 1745-47, Voltaire, ainda não tinha usado o seu principal trunfo contra a teodicéia (7, p.101), que seria, como sabemos, o Cândido.

No conto intitulado Visão de Babouc, de 1748, o personagem principal, chamado a julgar uma imaginária cidade de Persépolis, hesita constantemente em dar sua palavra definitiva, porque, se Persépolis tem defeitos, também tem qualidades. Entre os seus cidadãos, alguns são capazes de extrema baixeza, mas outros de extrema virtude. O mundo, representado por Persépolis, é uma mistura de bem e de mal. O melhor é aceitá-lo como ele é, nem bom nem mau, mas apenas sofrível (16, p. 88). Entretanto, Babouc é um estranho à cidade, e o mal que pode existir nela não o atinge pessoalmente. Daí a imparcialidade de seu julgamento. Tal não acontece com Menon, o personagem de outro conto do mesmo nome, datado de 1749. O projeto inicial de Menon é semelhante ao de Zadig: ser sábio, sem grandes paixões, sóbrio, independente. "Tendo assim em mente seu pequeno plano de sabedoria, Menon se pôs à janela' (16, p.90). Basta este pequeno gesto, o de olhar o mundo pela janela, e o mal se introduz imediatamente em sua vida. Entre sediçōes, chantagens e alterações, Menon perde um olho (como Zadig, aliás). Ao refletir sobre suas desgraças, o personagem considera que entre os vários mundos, "o nosso pequeno globo terrestre pode bem ser o hospício do universo', onde todos são completamente loucos. Se alguém dissesse que “tudo está bem', ele só acreditaria se pudesse recuperar sua visão perdida $(16, p .94)$. A lição do conto pode pois ser formulada da seguinte maneira: a idéia de que o mundo é ordenado providencialmente por um princípio benfeitor não resiste à simples apresentação de um fato singular que prove a existência do mal e da desordem. A crença na providência divina não basta nem para consolar os homens, e muito menos para satisfazer sua razão.

Um outro pequeno conto, Os dois consolados, apresenta a mesma conclusão. Nenhuma explicação teórica do mal satisfaz o homem. Apenas o tempo pode consolá-lo de suas tristezas. Já Scarmentado, viajante do conto do mesmo nome, após ter presenciado discussões, perseguições, violências e guerras, é o herói que se recusa a refletir sobre o que vê. Ele não diz uma palavra, ele não tem nada a responder quando o interro$\operatorname{gam}(13, \mathrm{p}-97-104)$.

Mas a grande investida de Voltaire contra a idéia de providência benfeitora é sem dúvida o Cândido, de 1759. Neste conto, a abundância de relatos onde os sintomas do mal no mundo se opõem a qualquer otimismo filosófico chega mesmo a um grau de saturação. Cândido, personagem que, como o próprio nome indica, é ingênuo, puro, solicito, presencia, durante suas aventuras, tudo o que a imaginação de Voltaire pode conceber como desgraça e miséria: guerras sem sentido, terremotos, a inquisição espanhola e as fogueiras de hereges, a escravidão, a doença, assassinatos a velhice, a feiura. O mundo descrito no conto, com exceção do episódio do Eldorado, é uma caricatura onde tudo o que é mau está incrivelmente acentuado e onde não resta nada de bom e agradável. Completamente aturdido, Cândido procura constantemente compreender a razão de tanta miséria, mas só encontra novas interrogaçōes. Se acompanharmos as reflexões do personagem através dos acontecimentos, observaremos que elas são sempre 
expressas como dúvidas e questòes, jamais como respostas. "Como é que uma boa causa pode produzir ef eitos abomináveis?" (10, p. 158). "Se este é o melhor dos mundos possíveis, como serão então os outros? (10, p. 161-162). "Fui cruelmente enganado quando acreditei que tudo vai o melhor possível no mundo" (10, p. 166). "Talvez o mundo das Américas seja melhor, pois é preciso confessar que só podemos lamentar este em que vivemos" (10. p. 170). "Que tudo está bem, seja; mas confesso que é bem cruel ter perdido Cunegundes e ainda ser queimado pelos orelhòes” (10, p.186). "O que é este mundo? Alguma coisa bem louca e abominável'’ (10, p. 213).

Na verdade, existem três proposições subjacentes a o conto que apontam para a solução do impasse criado pela constatação do mal no mundo face à idéia de um princípio providencial benfeitor. A primeira, sustentada por Pangloss, é o otimismo do filósofo Leibniz, e se expressa através do personagem da seguinte forma: “Está demonstrado que as coisas não podem ser de outra forma, pois, tudo tendo sido feito para um fim, tudo é feito necessariamente tendo em vista o melhor fim' (10, p.150). Ora, na primeira parte de seus Ensaios de Teodicéia, Leibniz se expressava de forma semelhante: "Ora, esta suprema sabedoria (de Deus), reunida a uma bondade que não é menos infinita, não pode deixar de escolher o melhor... Haveria alguma coisa a corrigir nas ações de Deus se ele tivesse podido fazer melhor... Se não houvesse o melhor entre todos os mundos possíveis, Deus não teria produzido nenhum', (6, p.150). Entretanto, a seqüência da fala de Pangloss no Cândido acrescenta ao otimismo de Leibniz um finalismo extremamente ingênuo que nada mais tem a ver com a Teodicéia. "Observe, continua Pangloss, que os narizes foram feitos para sustentar os óculos, e nós usamos óculos. As pernas foram feitas para usarem calças, e nós as usamos...' (10, p. 150). Ora, ao deturpar assim o chamado otimismo filosófico, Voltaire está visando outros adversários, alguns apologistas cristãos que, tal como Pangloss, sustentavam uma concepção finalista dos fenômenos, que era ao mesmo tempo ingênua e nitidamente antropomórfica. Mais tarde, ao retomar a questão das causas finais nas Questões sobre a Enciclopédia, Voltaire voltará a insistir sobre os limites da atribuição de uma finalidade a todos os fenômenos (11, p.199-200).

Evidentemente, o discurso otimista de Pangloss é justamente a tese contra a qual se constrói todo o edifício do conto. A princípio, Cândido o "escutava atenciosamente, e acreditava inocentemente", em meio às viagens, que o colocam em contato com a realidade do mal, ele se pergunta se não teria sido enganado; ele hesita mas não afirma nada. Mas, curiosamente, Cândido não opõem ao discurso de Pangloss nenhum outro discurso. O personagem que representa o otimismo filosófico sustenta a sua posição até a cena final do conto. Cândido, porém, não discute. Sua proposta é prática: cultivemos o nosso jardim.

A segunda solução para a questão do mal e da providência é sustentada pelo personagem Martin. “- Qual é, pergunta Cândido a Martin, sua opinião sobre o mal moral e o mal físico? - Senhor, responde Martin, meus padres me acusaram de ser sociniano; mas a verdade é que eu sou maniqueísta. - Você está zombando de mim, diz Cândido, não existem mais maniqueístas no mundo. - Existe, sou eu; eu não sei o que fazer, mas não posso pensar de outra forma."' (10, p.201). Diante do problema do sentido do mal no mundo, a posição de Martin é exatamente oposta a de Pangloss. Para este, nosso mundo é o melhor entre os mundos possíveis de serem criados por Deus; Martin , ao contrário, confessa que "dando uma olhada neste globo, ou melhor, neste glóbulo", ele não pode deixar de pensar que “Deus o abandonou a algum ser malfeitor' . Todavia, o maniqueísmo de Martin, embora admita a ação de dois seres no curso dos acontecimentos, um benigno, outro maligno, inclina-se muito mais a considerar o 
mal sobrepondo-se e como que escondendo o bem que possa existir. O próprio Cândido, que já viveu desgraças sem fim, espanta-se diante do pessimismo de Martin. “_Mas então, para que foi formado este mundo? pergunta Cândido. - Para nos deixar furiosos, responde Martin’' (10, p.204).

A terceira proposta ao problema do sentido do mal no mundo só aparece no capítulo final do conto, na voz de um derviche. Curiosamente, seu discurso é extremamente curto. Mas ainda, ele se recusa a proferir um discurso qualquer sobre o mal ou sobre o bem. Ansiosamente, Pangloss e Cândido esperavam ouvir do ancião uma resposta às suas questões. Para que o homem foi formado? Por que há tanto mal sobre a terra? O derviche apenas lhes devolve a questão: "Por que vocês se envolvem nisto? Que importa se há o mal sobre a terra? O melhor é calar diante destas questões (10, p.233-234). Martin e Pangloss insistem, e acabam levando a porta no nariz. A proposta do derviche é pois a do silêncio, a da não investigação, a da recusa da investigação filosófica sobre o sentido do mundo. Cândido, por sua vez, não se renderá definitivamente nem ao otimismo de Pangloss, nem ao pessimismo de Martin, nem ao ceticismo do derviche. Quanto à proposta final do cultivo do jardim, é evidente que a seu respeito várias interpretações são possíveis. Nenhuma delas, entretanto, invalida o fato de que o Cândido se apresenta como as "Confissões" de Voltaire, onde é narrada a decepção de um homem que procura a verdade absoluta. O conto se apresenta como investigação que ao final se nega como investigação.

Pudemos observar, pois, que Voltaire, durante mais de dez anos, desde a publicação de Zadig, em 1748, até a publicação de Cândido, em 1759, retoma em seus contos a questão filosófica do mal, recusando-se a dar a ela uma solução definitiva. Que sentido poderiamos atribuir a esta longa batalha sem desfecho? De que maneira esta questão do mal se situa no contexto filosófico da época das luzes, e, mais precisamente, em que medida ela se manifesta no discurso da corrente materialista?

De um modo geral, pode-se dizer que a filosofia do século XVIII, na medida em que afastou, através da crítica da revelação cristã, os conceitos de pecado original, imortalidade da alma e de castigo ou recompensa após a morte, viu-se às voltas com o problema do sentido do mal no mundo e da justificação da existência de Deus. Ora, do ponto de vista da filosofia materialista do barão d'Holbach, a questão deixa de existir através de uma explicação determinista dos fenômenos. A natureza, afirma Holbach, é totalmente desprovida de bondade ou de malícia; os fenômenos são simplesmente o que são. A noção de desordem é sempre subjetiva. O que chamamos o mal é sempre o ef eito de causas específicas, já conhecidas ou ainda ignoradas.

Diderot, no Sonho de d'Alembert, ao conceber a natureza como expressão de um surgimento contínuo de formas e fenômenos devidos ao acaso e à probabilidade, escapa a um determinismo rígido. Mas sua concepção af asta também de certo modo a questão do mal. "Nascer, viver e morrer é mudar de forma; que importa uma forma ou outra? Cada forma possui a felicidade ou a infelicidade que lhe é própria” $(2$, p. 95). Assim, tanto para Holbach como para Diderot, a questão do mal é resolvida na medida em que o consideramos como tal se apresenta, como ef eito necessário no curso dos fenômenos naturais.

O quadro das misérias do mundo descrito nos Diálogos sobre a religião natural, de Hume, é semelhante àquele em que o Cândido de Voltaire vive suas aventuras. "Se um estrangeiro viesse a aparecer de repente neste mundo, eu lhe apontaria, como uma amostra de seus males, um hospital cheio de doença, uma prisão cheia de malf eitores e devedores, um campo de batalha coberto de cadáveres, uma frota naufragando no oceano, uma nação definhando sob a tirania, a fome ou a peste' (4, p. 138-139). À questão de onde provém o mal, o personagem Fílon tem uma resposta: "Mas qual é, eu 
lhe pergunto, o objeto deste artifício e deste mecanismo delicados que ela (a natrureza) faz agir em todos os animais? Unicamente a preservação dos indivíduos e a propagação da espécie. Parece bastar à sua finalidade que tal ordem se mantenha no universo, sem nenhum cuidado ou preocupação acerca do bem-estar dos membros que a compõem', $(4$, p. 142). Trata-se, mais uma vez, da indiferença da natureza quanto ao que possa ser qualificado de bem ou de mal.

As proposições de Holbach, Diderot e Hume, embora de naturezas diferentes, possuem em comum o fato de, de um lado, não atribuírem a natureza nenhum fim que lhe seja exterior, e de outro, de não atribuírem ao ser humano nenhuma superioridade em relação aos outros seres. Tais propostas vêm acompanhadas pelo tema da contingência humana, presente na grande maioria dos textos da filosofia das luzes. La Mettrie, ao se perguntar sobre a razão da existência do homem, afirma que ela está possivelmente na sua própria existência. "Talvez tenha sido ele jogado ao acaso sobre um ponto da superfície da terra, sem que se possa saber nem como, nem por que, mas somente que ele deve viver e morrer, como aqueles cogumelos que aparecem de um dia para outro, ou como aquelas flores que bordejam os fossos e cobrem as muralhas' (5, p. 126). Holbach se expressa de forma semelhante, a oxortar os homens a aceitarem o fato de que são seres efêmeros (3, cap. VI, p. 105). Tal tema, o da contingência do homem, é comum também, como já vimos em capítulos anteriores, aos textos de Voltaire.

A explicação do mal pelas leis naturais e necessárias não satisfaz Voltaire. Já no Poema sobre o desastre de Lisboa, Voltaire havia levantado as respostas possiveis para justificar a existência do mal: a explicação pelo pecado ("Ou o homem nasceu culpado, e Deus puniu a raça'); a idéia de um deus indiferente ao mundo ("Ou este mestre absoluto do ser e do espaço/ sem cólera, sem piedade, tranqüilo, indiferente/ De seus primeiros decretos segue a eterna torrente'); e, por fim, a solução mais próxima do materialismo ("Ou a matéria informe, rebelde a seu mestre, carrega em si defeitos necessários como ela") (22, p. 307). O poeta, entretanto, recusa as soluções: "Não, não apresentem mais ao meu coração agitado estas leis imutáveis da necessidade’' (22, p. 305). É que, ao diluírem o problema do mal no curso necessário dos acontecimentos, tais soluções explicam o mal, mas não o justificam nem lhe dão sentido. Mas se Voltaire procura esta justificação, é porque o deísmo por ele adotado também não é satisfatório. Donde o impasse de Cândido, o seu silêncio, a sua proposta prática de abandonar a especulação e cultivar o jardim.

A partir da análise dos contos citados até agora, poderíamos dizer que, se eles, ao retomarem incansavelmente o problema do mal, se constituem inegavelmente como um argumento vigoroso contra a idéia de uma providência benfeitora, são também uma crítica menos manifesta, mas nem por isso menos real, às soluções da corrente materialista ao problema da desordem do mundo e da condição do homem, na medida em que, embora à disposição do autor, tais soluções não foram utilizadas como respostas às indagações de seus personagens.

Após a questão da providência e do mal, o segundo tema subjacente à grande parte dos contos se refere à natureza, origem e alcance do conhecimento humano. No interior desse tema, coloca-se primeiramente a necessidade da crítica do conhecimento metafísico. Os procedimentos de Voltaire em relação à metafísica são de caráter irônico. Zadig, por exemplo, conhecia da metafísica "tudo o que se poderia saber no seu tempo, quer dizer, quase nada”' (23, p. 5). O mesmo tratamento irônico é dado à "metafísico-teólogo-cosmolonigologia" de Pangloss. E o final inesperado do conto Micrômegas, em que o livro do mundo se apresenta totalmente em branco, significa exatamente a descrença do que possa ser metafísica. 
Para conhecer é preciso viajar. O tema da viagem, freqüente em toda a literatura do século XVIII, adquire nos contos filosóficos um papel fundamental. Micrômegas se põe a "viajar de planeta em planeta para acabar de formar o espírito e o coração" (19, p. 106). Em O branco e o negro, o sonho de Rustan se dá também como viagem. É durante inúmeras viagens que se dá o longo aprendizado de Cândido. Ora, a utilização deste tema não é simplesmente um recurso de estilo. A viagem possui para o personagem dos contos de Voltaire uma força demonstrativa (1, p. 120-170). Viajar é olhar o mundo. A visão, como um dos sentidos mais completos, tem a função de alargar o conhecimento e permite também o julgamento na medida em que sugere comparações. $\mathrm{O}$ tema da viagem está diretamente ligado ao empirismo de Voltaire.

A tese de que todo conhecimento se produz pelos sentidos aparece em observações esparsas em diversos contos. Vemos assim que os dois personagens do Micrômegas possuem, o saturniano, setenta e dois sentidos, o siriano, perto de mil; donde a pequenez do conhecimento do homem, pobre ser dotado de apenas cinco sentidos, em relação à ciência dos dois viajantes extraterrestres. O diálogo de Micrômegas com os filósofos terrestres faz aparecer como ridículas todas as teorias que não estabeleçam os sentidos como fonte de todo conhecimento. Assim, a enteléquia de Aristóteles, as idéias inatas de Descartes, a harmonia preestabelecida de Leibniz, são, para Micrômegas, apenas a prova de orgulho desta raça microscópica. Um só dentre os filósofos terrestres, partidário de Locke, lhe pareceu mais sensato: “Eu não sei, diz tal sábio, como eu penso, mas sei que só penso através dos meus sentidos”'.

As percepções oriundas dos sentidos, e armazenadas pela memória, constituem o fundamento de todo conhecimento humano. É esta a lição da pequena parábola, Aventuras da Memória (9, p. 501-504), um çonto que narra a confusão geral que se instauraria no mundo se nos faltasse a capacidade de guardar e de comparar as percepções vindas dos sentidos.

A contrapartida deste empirismo, no caso de Voltaire bastante primário, é o estabelecimento de limites intransponíveis ao conhecimento humano. Assim, em Micrômegas, o livro prometido pelo habitante de Sirius, no qual se poderia ver a finalidade do mundo, estava em branco. Na História de um bom brâmane, o sacerdote de Brahma enumera como impossiveis de serem atingidos, os conhecimentos sobre a eternidade, o infinito, a matéria, a natureza do pensar, o princípio do movimento. Trata-se de uma confissão, ao mesmo tempo das ambições de conhecer do homem e da ignorância que o impede de satisfazer tais ambições (14, p.124).

Alguns dentre os personagens dos contos são, temporária ou definitivamente, privados de meia visão. Zadig, Menon, Mesrour são personagens caolhos. Trata-se da visão infeliz, imagem dos próprios limites do homem, cuja razão está subordinada à experiência dos sentidos. Há momentos em que a viagem do conhecimento é interrompida. Assim, Zadig ainda insiste em discutir, mas o anjo Jesrad voa para os céus. Do mesmo modo, Cândido silencia Pangloss e Martin e propõe que abandonem a especulação para cultivarem o jardim.

A recusa das idéias inatas e a afirmação da experiência dos sentidos como fonte de todo conhecimento é um denominador comum à filosofia do século XV II I, sobretudo à corrente materialista. A tese do empirismo encontra-se na oitava prova das Memórias de Meslier, na ciência proposta por La Mettrie no Homem-máquina, no oitavo capítulo do Sistema da natureza. Mesmo Diderot, que dá uma importância muito grande à imaginação, permanece ainda um partidário do empirismo.

Voltaire assume esta epistemologia dos sentidos, mas se nega a propor af irmações que estejam além dos limites da percepção. O sensualismo dos filósofos materialistas, embora admita, como no caso de Holbach, o mecanismo de pensar que vai da simples 
sensação à percepção e ao conceito, não os impediu de enunciar principios metafísicos. Embora exista um personagem nitidamente materialista apenas num dos contos de Voltaire, a História de Jenni, o que se nota nos outros contos é uma critica ao materialismo que, segundo Voltaire, sustenta posiçōes dogmáticas a respeito de questões inacessiveis à mente humana, tais como o principio do movimento, a natureza da matéria e do pensar.

Mergulhado num mundo do qual ele não atinge o sentido, constrangido a limitar o seu conhecimento a poucas certezas, o homem dos contos de Voltaire se vê também determinado por forças sobre as quais não tem nenhum controle. Não se trata aqui, absolutamente, de forças de um destino misterioso e sobrenatural, mas de condições puramente materiais, fortuitas, e que desencadeiam o curso dos acontecimentos cotidianos antes mesmo que possamos reagir. Muitas vezes, o que é mais grave, tais condiçòes fortuitas e aparentemente sem importância são capazes de provocar ef citos completamente desproporcionais às suas causas.

Assim, por ter visto, sob sua janela, o cavalo do rei passar galopando, Zadig é condenado pelos tribuinais da Babilônia; por ter salvado uma mulher de ser agredida, se torna escravo de um mercador árabe. Menon dá inicio às suas infelizes aventuras pondo-se à janela. Um beijo atrás de um paravento, eis como começam as incriveis desgraças de Cândido. Mas é no conto intitulado As orelhas do conde de Chesterfield que Voltaire leva aos extremos do absurdo a idéia de que o destino do homem é regido por forças absolutamente materiais, desprovidas de qualquer sentido moral ou espiritual. Uma parte do diálogo entre o bem intencionado Goldman e o anatomista Sidrac é dedicada a destruir a noção de que o homem possui uma alma espiritual. Os homens se dão uma alma por pura vaidade. "Se um pavão pudesse falar, ele se vangloriaria de ter uma alma e diria que sua alma está na sua cauda"' (17, p.596). No sétimo capitulo, onde Goldman e Sidrac discutem "qual é o primeiro motor de todas as açòes humanas", Voltaire, pela voz de Sidrac, e de uma maneira extremamente irreverente, afirma que, em última instância, a história dos homens depende basicamente dos fenômenos da digestão e da evacuação. Não se trata apenas de correlacionar o temperamento do homem ao bom ou mau funcionamento dos intestinos, mas de fazer depender os negócios das nações e a história, em última instânca, ao muito ou pouco uso do banheiro. Cromwell, afirma Sidrac, ao assassinar seu rei; Henrique III, ao mandar assassinar o duque de Guise; o rei Carlos IX, ao permitir o massacre da noite de São Bartolomeu, estavam sem dúvida sob o ef eito dos humores intestinais que lhes subiram à cabeça. Ao se aproximar de um ministro de estado, é sempre bom saber se ele não sofre de prisão de ventre (17, p.604-606).

É verdade que o tema da correlação entre o físico e o moral é comum à filosofia materialista da época. É esta, inclusive, a tese principal que La Mettrie pretende demonstrar no Homem-máquina. Holbach, no Sistema da Natureza, define o homem como "um ser puramente físico; o homem moral é apenas o homem físico considerado sob um determinado ponto de vista"' (3, v.1, p.3). Entretanto, tal redução operada pelo materialismo (redução do homem a um ser físico) não exclui, dentre as causas possiveis das açōes dos homens, a influência das paixões, da educação, do maior ou menor brilho de sua imaginação e outras faculdades intelectuais. Se, de um lado, ao abandonar a teologia, o materialismo recusa ao homem qualquer vocação para o sublime religioso, pode-se dizer, de outro lado, que o sublime se reinsere no destino do homem através de outros ideais, tais como a luta contra a ignorância, o anseio da verdade, a busca da verdade etc. O que vale dizer que existe uma moral materialista, humanista e altruista. É, por exemplo, o caso de Meslier e Holbach. E, mesmo La Mettrie, cuja filosofia costuma ser apontada como imoral e amoral, apresenta, no 
Homem-máquina, uma exortação a certos valores morais como a necessidade de procurar a verdade e a coragem de dizê-la. Além disto, o fato de o homem ser concebido sob o modelo mecânico não lhe retira ao menos dois previlégios em relação aos outros animais, que são, segundo La Mettrie, sua organização mais sofisticada e sua disposição para ser educado.

A tese do anatomista Sidrac, no conto de Voltaire, desacata até mesmo os mais sérios materialistas. É evidente que não podemos considerar suas afirmações ao pé da letra. Mas, como imagem, a hipótese do personagem se ajusta com perfeição à proposta de Voltaire: persuadir, através da caricatura, de que, embora o homem procure sempre ilusões consolatórias para sua condição, ele não passa de um ser insignificante.

Ainda no ano de 1775, Voltaire publica um outro conto, História de Jenni, ou o ateu e o sábio, no qual a irreverência do estilo de Sidrac dá lugar ao tom de sermão do deísta Freind. O conto reúne todas as objeções de Voltaire contra o materialismo ateu. $\mathrm{Na}$ época de sua publicação, o Sistema da Natureza e o Bom Senso do barão d'Holbach, aliás explicitamente citado na História de Jenni, já haviam sido objeto de várias críticas por parte de Voltaire, e o conto apenas lhes empresta mais vigor, através da caracterização dos personagens.

$\mathrm{Na}$ periferia do conto, encontram-se os episódios sobre a inquisição espanhola, onde Voltaire mais uma vez exerce sua crítica da tradição eclesiástica romana. Já no espisódio do Haiti, vemos ressurgir o mito da pureza do homem selvagem. O tema central do conto é o diálogo entre o sábio e o ateu. Durante toda a narração observamos a permanência do tema da corrupção moral que o ateísmo pode provocar.

A descrição dos personagens centrais é rígida e procura realmente criar um tipo padrão de sábio e de ateu. O sábio, representado por Freind, é calmo, clemente, tolerante, virtuoso. Além disso, encarna com perfeição o deísmo de Voltaire. O ateu, por sua vez, apresenta-se como alguém eloqüente, bem informado, espirituoso, mas que costuma considerar verossimilhanças como demonstrações. Curiosamente, Voltaire desdobra o ateu em dois personagens: o primeiro, Clive Hart, cujo ateísmo está diretamente ligado a um comportamento maldoso e depravado. Trata-se da famosa tese sobre as más conseqüências morais do ateísmo. O segundo, Birton, é um ateu que Voltaire converte ao partido do sábio, através de uma longa reflexão sobre os argumentos que fundam o ateísmo.

Entre o ateu e o sábio, existe Jenni, filho de Freind, educado segundo a religião natural, e, como alguns personagens de outros contos, inocente, ingênuo e puro. Ele é, entretanto, progressivamente corrompido por um "bando de jovens ateus", "gente perdida". Sua ligação com os jovens ateus só lhe traz complicações e infelicidade. O próprio curso dos acontecimentos e mais sua participação passiva no diálogo entre Birton e Freind o trazem de volta à virtude e à felicidade. Tal como o filho pródigo, Jenni volta à casa do pai.

Através do discurso de Birton, Voltaire enumera cuidadosamente as razões que poderiam fundamentar o ateismo. Sucessivamente, Birton critica o argumento deista da ordem do universo, assinala nossa ignorância absoluta em relação a um suposto ser supremo, e, por último, utiliza contra o deismo de Freind o argumento dos defeitos do mundo e da existência do mal. Para Freind, a natureza inteira é arte, supondo pois um artesão. Para explicar o mal físico, Freind recorre às leis gerais impressas por Deus na natureza e é exatamente por. tê-las criado que Deus não interfere mais diretamente na criação. Por outro lado, o mal moral se explica pelo conceito de liberdade do homem. Finalmente, Freind recorre à idéia da possibilidade da sobrevivência do homem depois da morte, num lugar de recompensa para os justos, argumento tantas vezes criticado por Voltaire em outros contos. 
A parte final do discurso de Freind, que acaba por converter Birton definitivamente ao partido do sábio, apresenta o quadro piniado por Voltaire sobre os perigos morais do ateismo: “...Os laços da sociedade são rompidos, todos os crimes secretos inundam a terra...'. O fato de Voltaire recorrer à idéia da utilidade social da crença em Deus remunerador da virtude e vingador dos crimes tem sido amplamente discutido. Para alguns criticos, é perfeitamente normal que Voltaire faça uso deste argumento, uma vez que se trata de um expediente largamente difundido no século. Tal explicação deixa entretanto intacto o fato de que, na História de Jenni, Voltaire parece desmentir as proposições presentes nos outros contos, nos quais era evidente a recusa de qualquer ilusão consoladora para a condição do homem. Ora, é exatamente isso que Freind propõe. "Responda-me, senhor Birton, diz o sábio Freind, que mal pode nos fazer a adoração de um deus aliada à felicidade de ser um homem honesto? Nós podemos todos ser acometidos de uma doença mortal neste momento em que eu lhe falo: qual de nós então não gostaria de ter vivido na inocência? (12, p.586).

É curioso notar que entre o discurso de Birton e o de Freind, é o primeiro que parece se identificar com o próprio discurso de Voltaire em outros textos. "Ainda não é suficiente que o homem, esta nobre criatura, tenha sido tão mal alojado, tão mal vestido, tão mal alimentado durante tantos séculos. Ele nasce entre a urina e a matéria fecal para respirar dois dias. E durante estes dois dias, compostos de esperanças enganosas e de tristezas reais, seu corpo, formado com uma arte inútil, se encontra à mercê de todos os males que resultam desta mesma arte; ele vive entre a peste e a variola; a fonte de seu ser está envenenada; não há ninguém que possa guardar na memória a lista de todas as doenças que nos perseguem"' (12,p.569; 20,p.320; 21 ,p.478). Em alguns momentos do diálogo entre Freind e Birton, tem-se a impressão de que a reflexão do jovem ateu é tão convincente que poderá vir a derrotar os argumentos de Freind. Ora, é exatamente o contrário que acontece. Birton, apesar de todas as suas objeções, acaba por reconhecer a necessidade da crença num ser supremo.

O longo debate entre Birton e Freind revela, em última instância, a tensão presente no pensamento de Voltaire em relação ao tema da discussão. Na verdade, ele sustenta uma posição deista sem deixar de reconhecer as objeções possiveis ao deismo. Neste sentido, a maneira pela qual Birton cede ao raciocinio de Freind é significativa. Ele não diz claramente que está convencido; ele diz: "Seja! Existe um Deus, eu admito”. A expressão não sugere um acordo refletido, mas uma espécie de desistência diante de uma discussão que poderia não ter fim.

Por suas caracteristicas, a História de Jenni ocupa um lugar à parte entre os contos de Voltaire. Em certo sentido, trata-se de um conto mais completo, pois, no primeiro diálogo, entre o sábio e o fanático, nos mostra a luta de Voltaire contra a tradição cristã; no episódio do Haiti, o elogio da religião natural, sem culto, sem sacerdócio; no diálogo entre o sábio e o ateu, o combate de Voltaire contra todas as formas de ateismo; e, por último, através do discurso de Birton sobre a existência do mal, a retomada do tema da absurdidade do mundo e da justificação de Deus, presente em todos os outros contos. A História de Jenni também é, ao mesmo tempo, uma espécie de reedição, sob forma de ficção, do artigo "Deus" das Questões sobre a Enciclopédia, que inaugura a campanha de Voltaire contra o materialismo ateu do barão d'Holbach. 
NASCIMENTO, M. das (i.S. - Images of materialism in Voltaire's tales. Irans/form/Acão, Sào Paulo, 7:37-48, 1984.

ABSTRACT: Voltaire's philosophic tales organize themselves seting out from two reflection looles: on one hand, a discussion about the notion of a benefactor divine mrovidence, and, in some cases, more precisely, about the leibnizian optimism; on the other hand, the controversy around the atheistic materialism. We try to demonstrate through some situations and characters of the voltairean tales how the critique of the providencialist theories contributes to the delineation of the classical materialism 's concepts own universe.

LEY-W(ORISS: Voltaire; materialism; atheistic materialism; philosophic tales; philosophic sptimism; divine providence.

\section{REFERENCIAS BIBLIOGIRÁFICAS}

1. CHAUI, M de S. - Trêsem uma. In: Da Realidade sem mistérios ao mistério do mundo. São Paulo, Brasiliense, 1981.

2. DIDEROT, D. - Rêve de d'Alembert. Paris, G. Flamarion, 1965.

3. HOLBACH, P.H.T., Baron d' - Système de la nature, ou les lois du monde physique et du monde moral. Paris, Etienne ledoux, 1821.

4. HUME, D. - Dialogues sur la Religion naturelle. Utrecht, Pauvert, 1964.

5. LA METTRIE, J.O. de -- L'homme machine. Paris, Denoel-(ionthier, 1981.

6. L.EIBNIZ, (i.W. - Essais de théodicée sur la bonté de Dieu, la liberté de l'homme et l'origine du mal. Paris, Flamarion, 1967.

7. VAN DEN HEUVEl, J. - Romans, Contes et mélanges. Paris, Librairie Générale Française, 1972. v.I.

8. VAN DEN HEUVEL, J. - Voltaire dans les conte - De Microméges à l'Ingemu. Paris. Armand Colin, 1967.

9. VOLTAIRE, J.M.A. de - Aventure de la Mémoire, Romans et Contes. Paris, Ciallimard, Pléiade, 1967.

10. VOLTAIRE, J.M.A. de - Candide, ou l'optimisme, Romans el Contes. Paris, Gallimard, Pléiade, 1967.

11. VOLTAIRE, J.M.A. de - Dictionnaire philosophique. Paris, Garnier Frères, 1967.

12. VOLTAIRE, J.M.A. de - Histoire de Jenni, Romans et Contes. Paris, Gallimard, Pléiade, 1967.
13. VOLTAIRE, J.M.A. de - Histoire des voyages de Scarmentado, Romans et Contes. Paris, Gallimard, Pléiade, 1967.

14. VOlTAIRE, J.M.A. de - Histoire d'un bon bramin, Romans et Contes. Paris, Gallimard, Pléiade, 1967.

15. VOLTAIRE, J.M.A. de - L'Ingenu, Romans et Contes. Paris, Gallimard, Pléiade, 1967.

16. VOLTAIRE, J.M.A. de - Le monde comme il va, ou Vision de Babouc. Paris, Gallimard, Pléiade, 1967.

17. VOLTAIRE, J.M.A. de - Les oreilles du Comte de Chesterfield, Romans et Contes. Paris, Gallimard, Pléiade, 1967.

18. VOlTAIRE, J.M.A. de - Memnon ou la sagesse humaine, Romans et Contes. Paris, Gallimard, Pléiade, 1967.

19. VOLTAIRE, J.M.A. de - Micromégas, Romans et Contes. Paris, Gallimard, Pléiade, 1967.

20. VOLTAIRE, I.M.A. de - Oeuvres Complètes. Paris, Garnier Frères, 1877-1882. vol. 28.

21. VOLTAIRE, J.M.A. de - Oeuvres complètes. Paris, Garnier Frères, 1877-1888. vol. 30.

22. VOlTAIRE, J.M.A. de - Poème sur le désastre de Lisbonne, Mélanges. Paris, Pléiade, 1965.

23. VOLTAIRE, J.M.A. de - Zadig, Romans el Contes. Paris, Gallimard, Pléiade, 1967. 